\title{
PERENCANAAN STRATEGIS UNTUK MENEKAN TINGKAT KEHILANGAN AIR PDAM SURABAYA DENGAN SISTEM DINAMIK
}

\author{
Ruli Utami ${ }^{(1)}$, Erma Suryani ${ }^{(2)}$ \\ Jurusan Sistem Informasi, ITATS ${ }^{1}$ \\ Jl. Arief Rachman Hakim 100 Surabaya, 60111 \\ Jurusan Sistem Informasi, Fakultas Teknologi Informasi, ITS ${ }^{2}$ \\ Kampus Keputih, Sukolilo Surabaya, 60111 \\ E-mail: ruli.utami03@gmail.com
}

\begin{abstract}
Water losses distribution is a serious problem in PDAM Surabaya, because in the period 1995-2014 recorded a 30\% water that is not distributed to the customer caused by technical leaked, and $45 \%$ because of missing consumption (illegal). This causes disanvantage of material for PDAM Surabaya and customers. With modeling and simulation using dynamic system to reduce the level of water losses. Then recommended several policies that can be taken by PDAM Surabaya to reduce the number of water losses, which is the scenario do nothing, at an average prediction rate of water losses by the year 2035 is 68,6\%. From the repairing of the pipeline scenario, in obtaining the resulting increase in revenue of 5 billion for each $1 \%$ change of the damaged pipe (with a maximum limit of repair is $5 \%$ per year with an increase of $3.6 \%$ fulfillment ratio). So the rate of decline in the level of losses will depend on how many percent of the pipe that can be rectified by PDAM annually. The last scenario (conversion losses to a new customers) produces an average of 266.255 household customers new customers or industries amounted to 9.830 new customers or 14.841 new customers of government's agency or 135.022 commercial's customer new customers or outside the city new customers 701 or 773 port new customers or 32.280 new social new customers.
\end{abstract}

Keywords: Dynamic System, PDAM, Water Losses

\begin{abstract}
ABSTRAK
Kehilangan air dalam distribusi merupakan masalah yang cukup serius pada PDAM Surabaya, karena dalam kurun waktu 1995-2014 tercatat 30\% air yang di distribusikan tidak sampai pada pelanggan karena bocor teknis, dan 45\% karena konsumsi hilang(ilegal). Hal ini menyebabkan kerugian material baik pada PDAM Surabaya ataupun pelanggan. Dengan pemodelan dan simulasi menggunakan sistem dinamik untuk menekan tingkat kehilangan air. Maka di rekomendasikan beberapa kebijakan yang dapat di ambil oleh PDAM Surabaya untuk menekan angka kehilangan air, yaitu dengan skenario do nothing, di prediksi rata-rata rasio kehilangan air hingga tahun 2035 adalah sebesar 68,6\%. Dari skenario pergantian pipa, di peroleh hasil peningkatan pendapatan sebesar 5 milyar untuk setiap pergantian $1 \%$ pipa yang rusak(dengan batas maksimal pergantian adalah $5 \%$ pertahun) dengan peningkatan rasio pemenuhan sebesar 3,6\%. Jadi tingkat penekanan tingkat kehilangan akan tergantung pada berapa persen pipa yang dapat di perbaiki oleh PDAM setiap tahunnya. Skenario terakhir(konversi kehilangan ke pelanggan baru) menghasilkan rata-rata pelanggan Rumah tangga sebesar 266.255 pelanggan baru atau industri sebesar 9.830 pelanggan baru atau instansi pemerintah14.841 pelanggan baru atau pelanggan niaga135.022 pelanggan baru atau luar kota 701 pelanggan baru atau pelabuhan 773 pelanggan baru atau sosial 32.280 pelanggan baru.
\end{abstract}

Kata kunci : Sistem Dinamik, PDAM, Kehilangan Air

\section{PENDAHULUAN}

Air merupakan kebutuhan pokok bagi masyarakat, sebagai perusahaan daerah yang bertanggungjawab atas pemenuhan kebutuhan air bersih bagi masyarakat, PDAM harus memiliki langkah strategis untuk jangka panjang dan berkelanjutan untuk memenuhi kebutuhan 
pelanggannya[1]. Dengan cakupan layanan yang luas; pelanggan PDAM terbagi menjadi dua kelompok pelanggan yaitu pelanggan domestik yang mencakup kelompok rumah tangga dan pelanggan non domestik yang mencakup kelompok indutri, niaga, instansi pemerintah, pelabuhan, sosial, dan luar kota. Dari data Badan Statistik Surabaya (BPS), jumlah pelanggan ini terus meningkat secara linier setiap tahunnya, dengan total pelanggan sebesar 514.613 pada tahun 2014. Dan jumlah ini di perkirakan akan terus meningkat [2].

Dengan jumlah pelanggan tersebut di atas dan kuantitas produksi sebesar 300 juta m 3 pertahun dan jumlah konsumsi $180 \mathrm{lt} / \mathrm{hr} /$ orang, maka rasio pemenuhan kebutuhan yang dapat di cover oleh PDAM Surabaya baru berkisar pada angka 50,3\%[3]. Selain jumlah konsumsi yang besar, permasalahan yang belum terselesaikan oleh PDAM Surabaya adalah besarnya tingkat kehilangan pada distribusi air bersih yang mencapai angka $45 \%$ untuk air hilang karena konsumsi ilegal, dan 30\% hilang karena bocor teknis pada kurun tahun 1995-2014 [2]. Menurut Internasional Water Assosiations, kehilangan bisa terjadi karena adanya konsumsi tak resmi, ketidak akuratan meteran pelanggan, kesalahan data, kebocoran pipa transmisi dan pipa induk, kebocoran dan luapan pada Tanki reservoir, dan kebocoran pada pipa pelanggan [4]. Namun yang akan di bahas dalam penelitian ini terbatas pada bagaimana menekan tingkat kehilangan (yang bersumber dari konsumsi tak resmi dan kebocoran pipa pelanggan) untuk optimalisasi rasio pemenuhan kebutuhan pelanggan.

\section{TINJAUAN PUSTAKA}

\section{Sumberdaya Air}

Sumberdaya merupakan potensi nilai yang dimiliki oleh suatu materi atau unsur tertentu dalam kehidupan. Hutan, tanah, air, dan tanaman pertanian adalah merupakan contoh bentuk sumber daya alam yang dapat di perbarui [5]. Dalam hal sumberdaya air, di bagi menjadi sumberdaya air yang bersumber dari air permukaan, air tanah, dan mata air[6]. Untuk air permukaan, PDAM Kota Surabaya memiliki sumberdaya air utama yakni air permukaan yang berasal dari Daerah Aliran Sungai(DAS) Sungai Brantas dan Sungai Kalimas. Sedangkan untuk mata air, berasal dari mata air Umbulan yang terletak di Pandaan, dan air tanah tidak digunakan oleh PDAM untuk melindungi lingkungan [7].

Tabel 1. Daftar DAS Kota Surabaya

\begin{tabular}{clccl}
\hline No & Nama Sungai & Panjang(m) & $\begin{array}{c}\text { Kec. } \\
\text { Air(m/dt) }\end{array}$ & \multicolumn{1}{c}{ Pemanfaatan } \\
\hline 1 & Kali Surabaya & 17400 & 0.119 & $\begin{array}{l}\text { Pasokan bahan baku } \\
\text { PDAM }\end{array}$ \\
\hline 2 & Kali Wonokromo & 12100 & 0.425 & $\begin{array}{l}\text { Pasokan bahan baku } \\
\text { PDAM }\end{array}$ \\
\hline 3 & Kali Lamong & 9770 & 0.128 & Drainase \\
\hline 4 & Kali Perbatasan & 12670 & 0.093 & Drainase \\
\hline 5 & Kali Mas & 11160 & 0.143 & Drainase \\
\hline 6 & Kali Kedurus & 16380 & 0.091 & Drainase \\
\hline
\end{tabular}

\section{Analisa Ketersediaan dan Kebutuhan Air}

Untuk memenuhi kebutuhan air penduduk Surabaya, maka dilakukan pengolahan (produksi) air yang di pusatkan pada enam Instalasi Pengelolaan Air Minum (IPAM) yang di miliki oleh PDAM Surabaya. IPAM ini adalah IPAM Ngagel I dengan kapasitas produksi maksimal 1800 lt/dt, IPAM Ngagel II dengan kapasitas produksi maksimal 1000 lt/dt, IPAM Ngagel III dengan kapasitas produksi maksimal 1750 lt/dt, IPAM Karangpilang I dengan kapasitas produksi maksimal 1450 lt/dt, IPAM Karangpilang II dengan kapasitas produksi maksimal 2750 lt/dt, IPAM Karangpilang III dengan kapasitas produksi maksimal 2000 lt/dt. Pengelolaan air ini memanfaatkan aliran air Brantas dan Kalimas sebagai bahan baku air [8].

Sedangkan untuk kebutuhan air, dikategorikan menjadi dua yaitu kebutuhan air domestik dan 
non domestik. Kebutuhan air domestik adalah kebutuhan air yang digunakan untuk keperluan rumah tangga yaitu untuk keperluan minum, memasak, mandi, cuci pakaian serta untuk keperluan lainnya. Sedangkan kebutuhan air non domestik digunakan untuk kegiatan komersil seperti industri, perkantoran, maupun kegiatan sosial seperti sekolah, rumah sakit, tempat ibadah, niaga, asrama, rumah sakit, militer, serta pelayanan jasa umum lainnya[9].

\section{Kehilangan Air}

Kehilangan air merupakan salah satu faktor yang dapat menyebabkan kerugian baik terhadap PDAM sebagai penyedia air bersih, maupun terhadap konsumen yang berakibat terganggunya kapasitas dan kontinuitas pelayanan untuk menggunakan air bersih [10]. Kehilangan air bersih perpipaan atau air bersih, adalah jika komponen air yang sah di konsumsi oleh pelanggan tetapi tidak tercatat (konsumsi ilegal tak bermeteran atau karena kebocoran pipa pelanggan) [11]. Sehingga tidak dapat di konversikan menjadi pendapatan oleh pengelolah air bersih. Untuk mengetahui jumlah air yang hilang (losses), maka di gunakan rumus:

Kehilangan Air = Jumlah Air di Pasok - Jumlah Air yang di Konsumsi

Sedangkan Tingkat Kehilangan Air adalah porsentase perbandingan antara kehilangan air dan jumlah air yang di distribusikan ke jaringan perpipaan.

Tingkat Kehilangan Air $=\frac{\text { Kehilangan Air }}{\text { Jumlah Air Yang di Pasok }} \times 100 \%$

Sehingga kehilangan air dapat didefinisikan sebagai selisih antara jumlah air yang di distribusikan di kurangi air yang di konsumsi(resmi). Kehilangan air harus di hitung berdarkan total volume (jumlah) yang di produksi hingga yang di distribusikan.

\section{Sistem Dinamik}

Pendekatan sistem dinamik dimulai dari pendefinisian masalah secara dinamis dari waktu ke waktu, dilanjutkan dengan tahap pemetaan dan pemodelan variable signifikan yang mempengaruhi [12]. Setelah variabel dirasa cukup, selanjutnya yaitu pengembangan stock and flow diagram. Pada tahap ini proses yang dilakukan yaitu identifikasi arus masuk atau akumulasi (level) dalam sistem dan arus keluar (rate). Tahap selanjutnya yaitu pengembangan model dan disimulasikan dengan bantuan komputer lalu mengumpulkan pemahaman dan kebijakan yang berlaku dari model yang dihasilkan. Langkah-langkah yang terlibat dalam simulasi [13]:

1) Pendefinisian masalah yang meliputi: penentuan batasan masalah dan identifikasi variabel yang signifikan.

2) Formulasi model: merumuskan hubungan antar komponen-komponen model.

3) Pengambilan data yang diperlukan sesuai dengan tujuan pembuatan model.

4) Pengembangan model.

5) Verifikasi model terhadap error.

6) Validasi model, apakah model yang dibuat sudah sesuai dengan sistem nyata. Dua cara validasi yaitu [14]:

Perbadingan Rata-Rata (Mean Comparison)

$\boldsymbol{E} 1=\frac{\mid \bar{S}-\bar{A}\rfloor}{\bar{A}}$

Di mana:

$\bar{S}=$ standard deviasi model

$\bar{A}=$ standard deviasi data

Model dianggap valid bila $E 1 \leq 5 \%$ 
Perbandingan Variasi Amplitudo (Variance Comparison)

$E 2=\frac{|s s-S a|}{S a}$

Di mana:

Ss $=$ standard deviasi model

$\mathrm{Sa}=$ standard deviasi data

Model dianggap valid bila E2 $\leq 30 \%$

7) Setelah model valid maka langkah selanjutnya adalah membuat beberapa skenario (eksperimen) untuk memperbaiki kinerja sistem sesuai dengan keinginan. Jenis-jenis skenario:

- Skenario parameter dilakukan dengan jalan mengubah nilai parameter model. Relatif mudah dilakukan karena hanya melakukan perubahan terhadap nilai parameter model namun dampaknya hanya terhadap output model.

- Skenario struktur dilakukan dengan jalan mengubah struktur model.Skenario jenis ini memerlukan pengetahuan yang cukup tentang sistem agar struktur baru yang diusulkan/dieksperimenkan dapat memperbaiki kinerja sistem.

8) Interpretasi model. Proses ini merupakan penarikan kesimpulan dari hasil output model simulasi.

9) Implementasi, penerapan model pada sistem.

10) Dokumentasi, merupakan proses penyimpanan hasil output model.

\section{METODE}

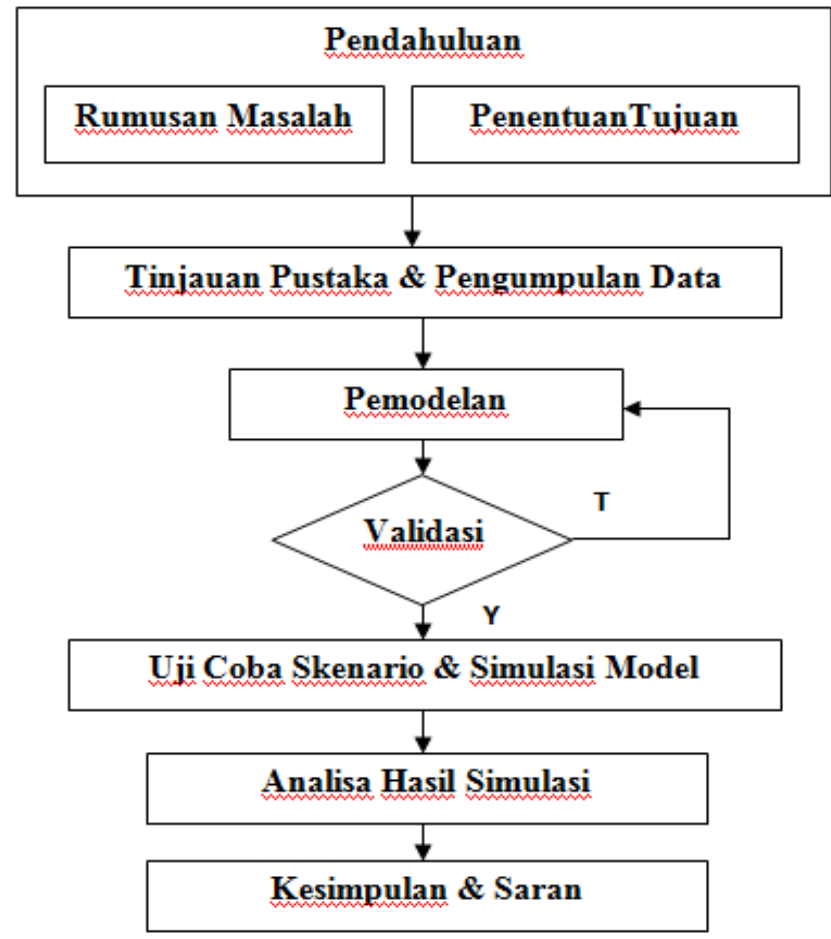

Gambar 1. Metode Penelitian

Penelitian ini dilakukan dengan metode sistem dinamik dengan kurun waktu data 1995 hingga 2014, hal ini dilakukan untuk memprediksi rasio kehilangan air yang terjadi pada PDAM Surabaya hingga 25 tahun ke depan (2035). Adapun tahapan yang akan di lakukan dala penelitian telah di sajikan dalam gambar 1 di atas. 


\section{HASIL DAN PEMBAHASAN}

\section{Analisa Kondisi Saat Ini Melalui Base Model}

Causal loop Diagram(CLD) merupakan gambaran hubungan antar variabel yang membentuk rantai sebab akibat dan umpan balik antar variabel. Dari gambar di di bawah, dapat di ketahui bahwa jumlah produksi di pengaruhi oleh jumlah IPAM dan debit masing-masing reservoir. Sedangkan konsumsi(distribusi) di pengaruhi oleh jumlah produksi, jumlah pelanggan, yang hilang(akibat konsumsi ilegal), dan air yang hilang akibat pipa bocor. Sedangkan total kehilangan air(losses) di pengaruhi oleh jumlah air yang hilang(akibat konsumsi ilegal) dan air yang hilang akibat pipa bocor.

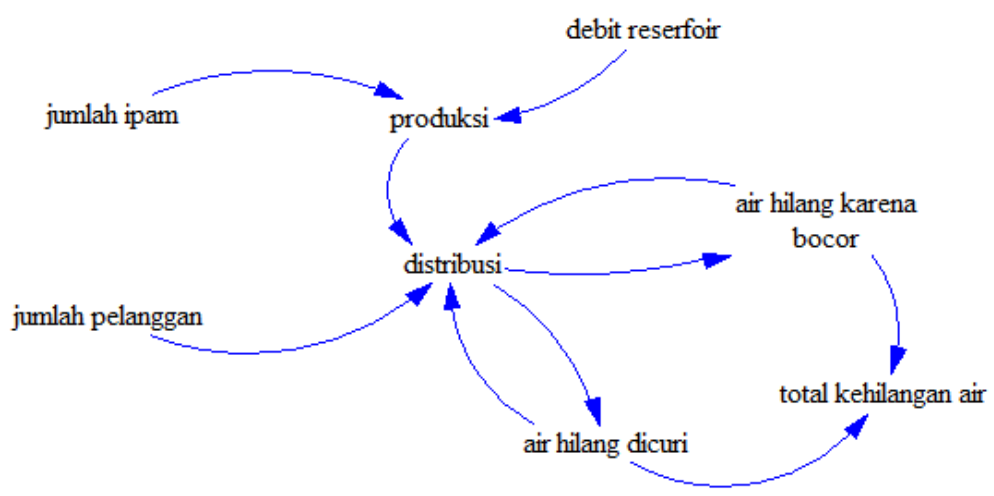

Gambar 2. Causal Loop Diagram Kehilangan Air PDAM

Base Model debit reservoir di analisa berdasarkan data dari Badan Pusat Statistik, masingmasing debit reservoir IPAM Surabaya bervariasi antara satu IPAM dengan IPAM yang lain. Pada tahun 2015 kapasitas debit reservoir untuk ngagel I adalah 1800 lt /dt, ngagel II sebesar $1000 \mathrm{lt} / \mathrm{dt}$, ngagel III sebesar $1750 \mathrm{lt} / \mathrm{dt}$, karang pilang I sebesar $1450 \mathrm{lt} / \mathrm{dt}$, karang pilang II sebesar $2750 \mathrm{lt} / \mathrm{dt}$ dan untuk karang pilang III sebesar 2000 lt/dt. Sedangkan untuk rata-rata setiap tahunnya; debit reservoir untuk ngagel I adalah 1505 lt/dt, ngagel II sebesar 882 lt/dt, ngagel III sebesar $1433 \mathrm{lt} / \mathrm{dt}$, karang pilang I sebesar $1263 \mathrm{lt} / \mathrm{dt}$, karang pilang II sebesar $2234 \mathrm{lt} / \mathrm{dt}$ dan untuk karang pilang III sebesar 1579 lt/dt. Hal ini dapat dilihat pada gambar 18 dan 19 di bawah ini.

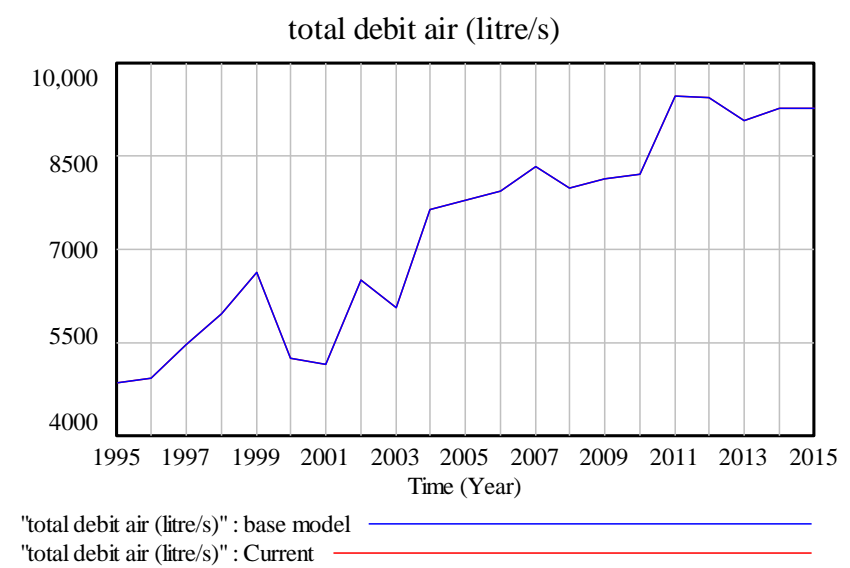

Gambar 3. Grafik Debit Reservoir Air PDAM

Pada tahun 2015, kisaran rata-rata produksi PDAM Surabaya adalah 300 juta m3 dalam setahun. Untuk menghitung total kapasitas produksi oleh PDAM Surabaya, maka harus di ketahui masing-masing debit reservoir lebih dahulu. Kemudian baru di kalikan dengan koefisien masingmasing satuan. Rumus untuk menghitung total produksi dapat di hitung sebagai berikut. 
Total Produksi $=$ debit reservoir $*$ koefisien liter ke $m 3 *$ koefisien detik ke jam $*$ koefisien jam ke hari * koefisien hari ke tahun

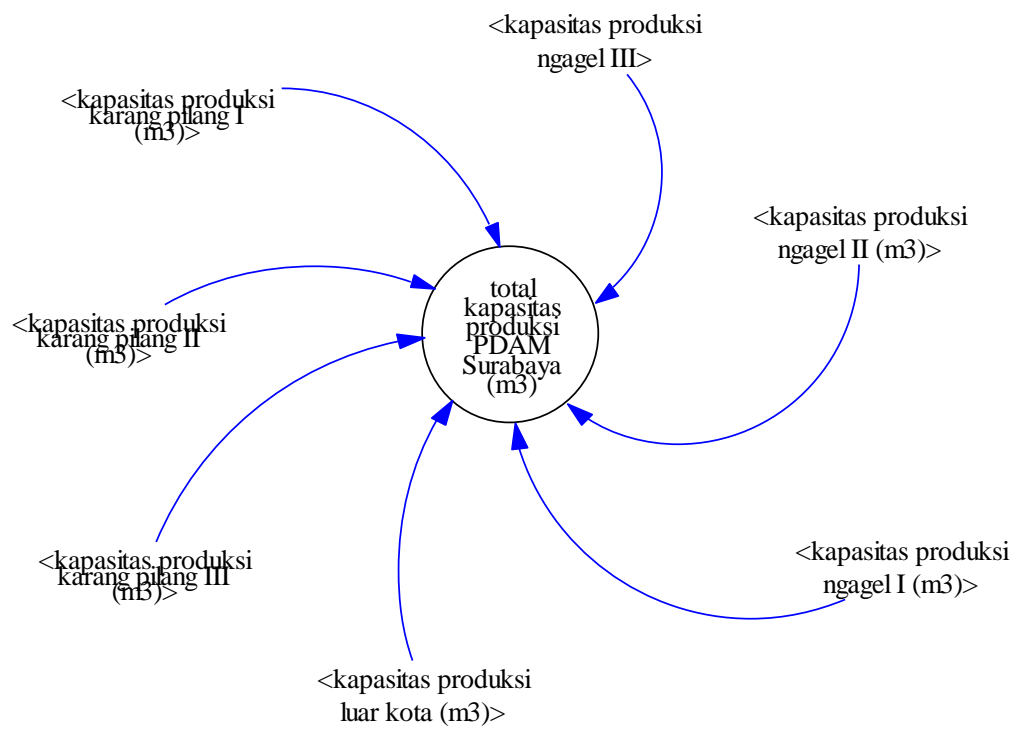

Gambar 4 Model Total Kapasitas Produksi PDAM Surabaya

Total konsumsi Air PDAM Surabaya di hitung dari konsumsi domestik di tambah total konsumsi non domestik yang berasal dari pelanggan sosial, industri, instansi pemerintah, luar kota, niaga, pelabuhan, dan pelanggan penjualan. Dari model di bawah, dapat di hitung bahwa jumlah konsumsi sebenarnya di bawah angka prosuksi. Namun pada kenyataannya rasio pemenuhan yang dapat di lakukan oleh PDAM Surabaya hingga tahun 2015 masih berkisar pada angka 50,3\%.

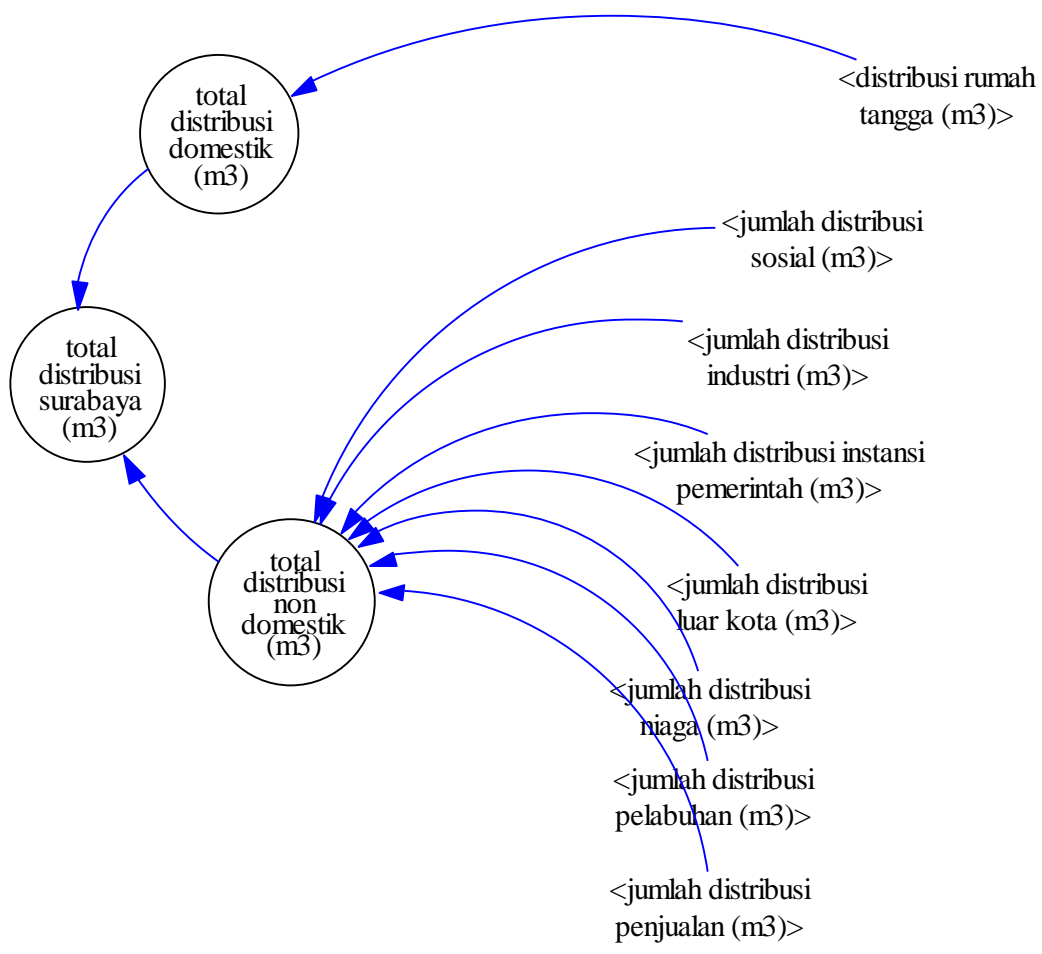

Gambar 5. Grafik Total Konsumsi PDAM Surabaya

Sedangkan untuk rasio kehilangan air dapat di hitung dari jumlah total produksi di kurangi dengan total kehilangan air (water losses). Sehingga dapat di hitung bahwa rata-rata jumlah kehilangan air dalam kurun waktu 1995-2014 adalah sebesar 74\%. 


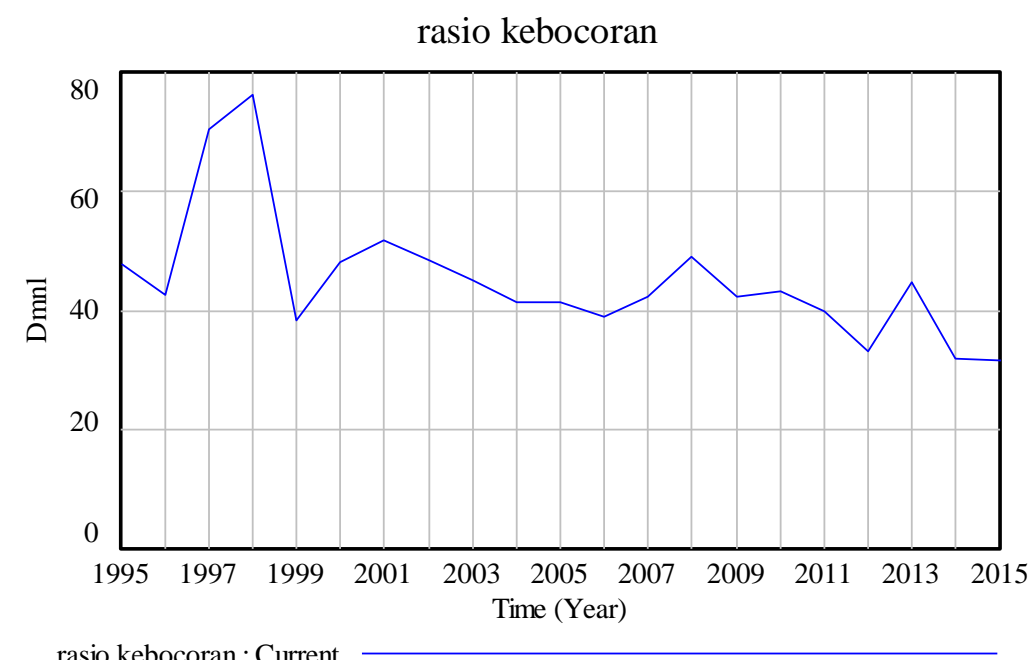

Gambar 6. Grafik Rasio Kehilangan(Losses) Air PDAM Surabaya

\section{Validasi Model Untuk Tingkat Kehilangan Air}

Perbandingan yang di dapat dari data yang ada adalah seperti gambar di bawah ini, dari grafik di bawah, bias di lihat bahwa antara data riil dan data simulasi hampir serupa yang artinya data simulasi dapat menggambarkan kondisi saat ini, sehingga perhitungannya dapat di katakana valid. Untuk perhitungan selengkapnya dapat di lihat pada tabel 2.

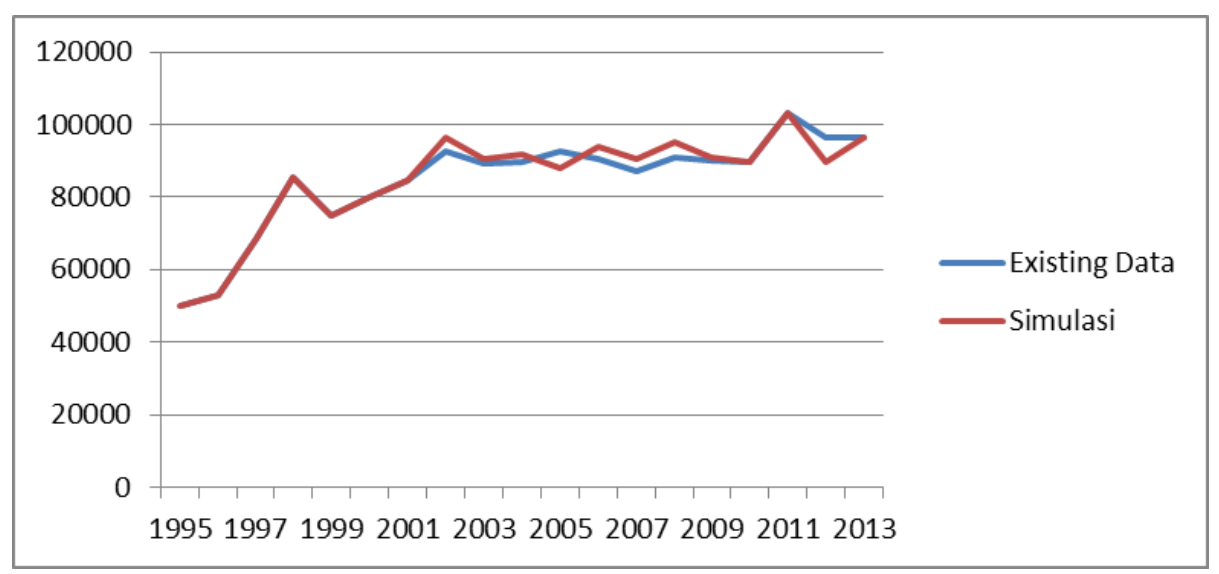

Gambar 7. Grafik Perbandingan Data Riil Dan Simulasi Pada Tingkat Kehilangan Air PDAM Surabaya

Dari data di bawah, diketahui bahwa nilai rata-rata riil dari air hilang sebesar 84465.37 dengan standart deviasi untuk data riil sebesar 13922.3, dan untuk rata-rata data simulasi adalah sebesar 84869.72 dengan standart deviasi sebesar 14135.41. Dari data tersebut dapat ditentukan E1 dan E2, dimana E1 ini adalah nilai rata-rata dari data riil dikurangi dengan nilai rata-rata data model simulasi dibagi dengan nilai rata-rata data riil, dan nilai E1 tidak boleh lebih besar sama dengan 5\%. Nilai E1 untuk sub model air hilang adalah $0.48 \%$, sehingga E1 dinyatakan valid. Sedangkan E2 adalah merupakan nilai standart deviasi model dikurangi dengan nilai standart deviasi data riil dibagi dengan nilai standart deviasi data riil dan nilai E2 tidak boleh lebih sama dengan 30\%. Nilai E2 untuk sub model air hilang adalah $1.53 \%$, sehingga E2 dinyatakan valid.

Karena $\mathrm{E} 1<=5 \%$ dan $\mathrm{E} 2<=30 \%$, maka sub model air hilang dinyatakan valid atau menggambarkan kondisi sstem nyata. Berikut ini adalah perbandingan grafik antara data riil dengan data sub model air hilang. 
Tabel 2. Validasi Model Tingkat Kehilangan Air

\begin{tabular}{|c|c|c|}
\hline $\begin{array}{l}\text { Time } \\
\text { (Year) }\end{array}$ & $\begin{array}{l}\text { ED Jumlah } \\
\text { Distribusi Hilang }\end{array}$ & $\begin{array}{l}\text { Simulasi Jumlah } \\
\text { Distribusi Hilang }\end{array}$ \\
\hline 1995 & 50096 & 50096 \\
\hline 1996 & 53100 & 53100 \\
\hline 1997 & 68686 & 68686 \\
\hline 1998 & 85258 & 85258 \\
\hline 1999 & 74842 & 74842 \\
\hline 2000 & 79862 & 79862 \\
\hline 2001 & 84686 & 84686 \\
\hline 2002 & 92473 & 96372.00781 \\
\hline 2003 & 89192 & 90645.00781 \\
\hline 2004 & 89458 & 91764.95313 \\
\hline 2005 & 92762 & 88033.03906 \\
\hline 2006 & 90456 & 94015.94531 \\
\hline 2007 & 87255 & 90405.25781 \\
\hline 2008 & 90787 & 95131.85938 \\
\hline 2009 & 89987 & 90763.4375 \\
\hline 2010 & 89793 & 89793 \\
\hline 2011 & 103071 & 103071 \\
\hline 2012 & 96539 & 89460.14063 \\
\hline 2013 & 96539 & 96539 \\
\hline Average & 84465.37 & 84869.72 \\
\hline Std & 13922.30 & 14135.41 \\
\hline $\mathrm{E} 1<5 \%$ & 0.004787168 & $0.48 \%$ \\
\hline $\mathrm{E} 2<30 \%$ & 0.015306921 & $1.53 \%$ \\
\hline
\end{tabular}

\section{Hasil Skenario}

Setelah model yang dikembangkan dinyatakan cukup valid, maka langkah berikutnya adalah penyusunan skenario simulasi sesuai dengan skenario kebijakan yang akan diputuskan. Adapun time frame yang digunakan adalah mulai tahun 2016-2035. Beberapa skenario kebijakan yang di rekomendasikan adalah skenario do nothing, skenario pergantian pipa, dan skenario konversi konsumsi ilegal ke jumlah pelanggan baru(pemasangan baru).

Dengan skenario kebijakan do nothing pada tingkat kehilangan air PDAM Surabaya pada time frame 2016-2035, hasil simulasi menunjukkan prosentase tingkat kehilangan adalah 68,6\% . 


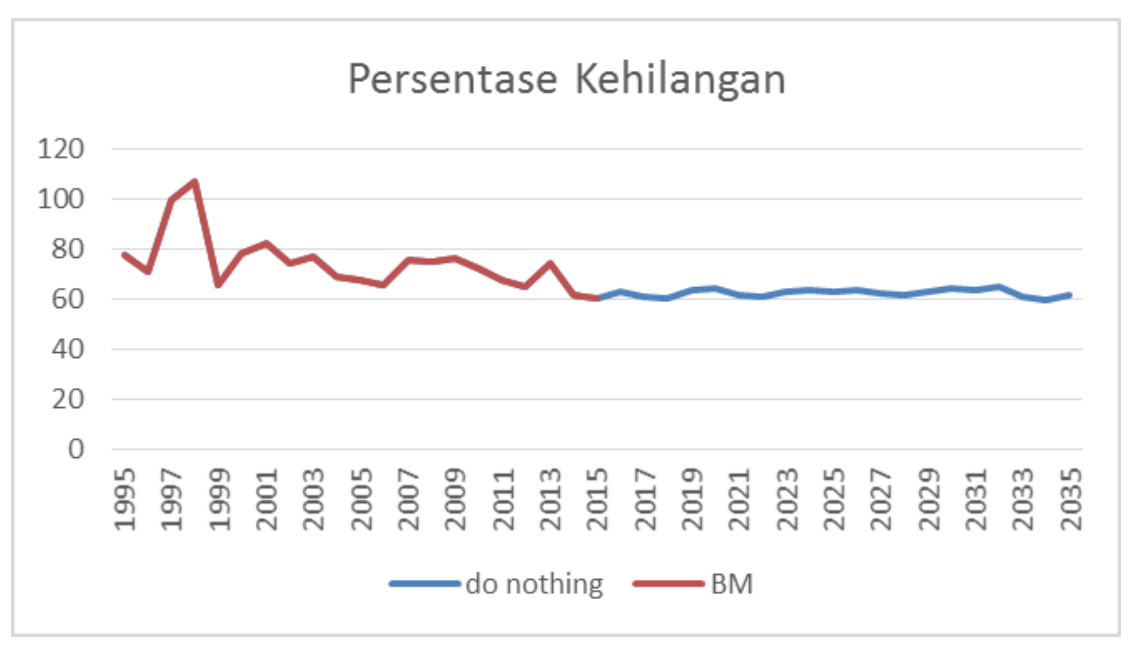

Gambar 8. Grafik Skenario do nothing Pada Tingkat Kehilangan Air

Skenario kedua yang di rekomendasikan penulis adalah skenario pergantian pipa yang bocor. Total jaringan pipa yang di miliki oleh PDAM Surabaya hingga tahun 2010 adalah sepanjang 300 $\mathrm{Km}$, dan berkembang menjadi $5.400 \mathrm{Km}$ pada tahun 2014. Dengan melakukan pergantian pipa yang bocor, akan meningkatkan pendapatan PDAM Surabaya dengan kisaran pendapatan 5 milyar per 1\% pipa bocor yang di ganti. Adapun biaya untuk penggantian pipa adalah sebesar 300 juta per kilometer. Untuk skenario pergantian pipa PDAM Surabaya, di targetkan akan mencapai angka 5\% dalam setahun.

Jika skenario pergantian pipa yang di rekomendasikan oleh penulis akan dijalankan oleh PDAM Surabaya, maka hal ini akan berpengaruh pada peningkatan rasio pemenuhan kebutuhan pelanggan sebesar 3.6\%. perhatikan gambar 80 di bawah ini.

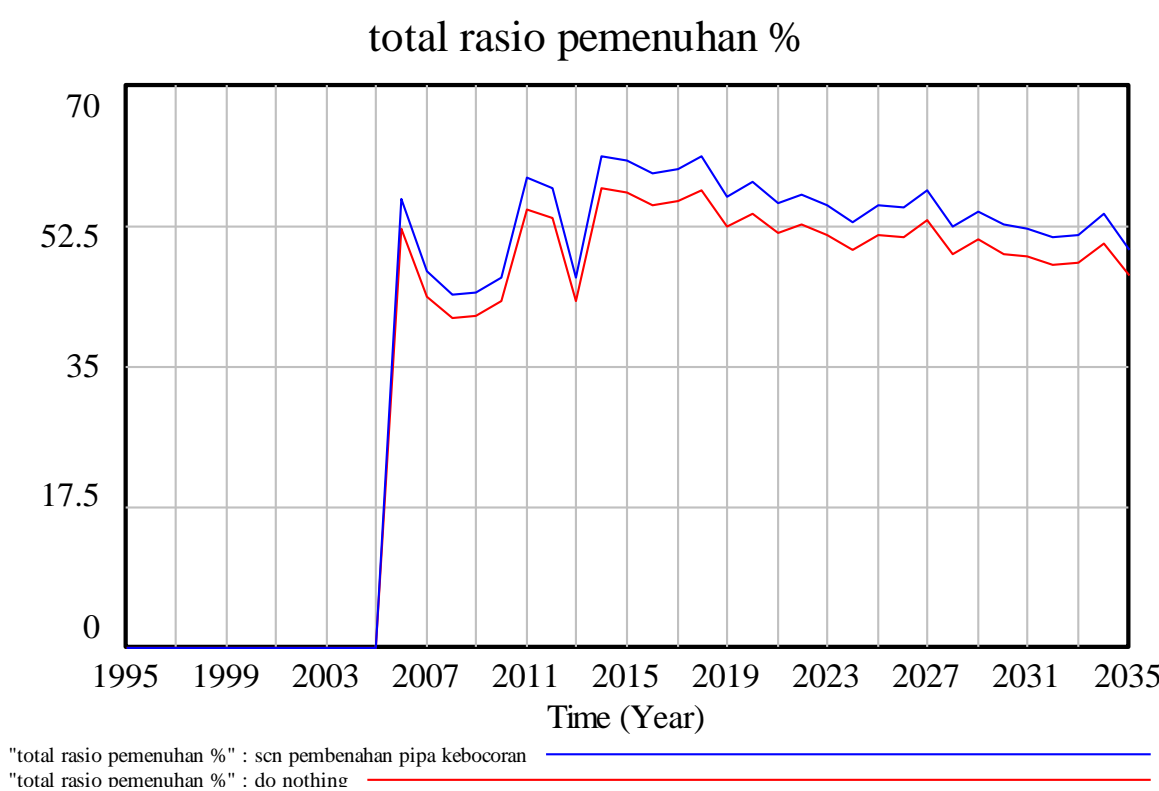

Gambar 9. Grafik Rasio Peenuhan Dengan Skenario Pergantian Pipa Bocor

Pada skenario do nothing, jumlah kehilangan untuk air hilang (konsumsi ilegal) pada tahun 2035 adalah sebesar $88.238 .792 \mathrm{~m}^{3}$. Dalam upaya pembenahannya, dapat di rekomendasikan kebijakan untuk mengkonversi jumlah hilang (konsumsi ilegal) tersebut ke dalam jumlah pelanggan baru dengan melihat rata-rata konsumsi per pemasangan dari masing masing jumlah pelanggan. Ratarata konsumsi perpemasangan pelanggan rumah tangga adalah $346.49 \mathrm{~m}^{3}$, pelanggan industri 
$9384.69 \mathrm{~m}^{3}$, pelanggan instansi pemerintah $6215.96 \mathrm{~m}^{3}$, pelanggan niaga $683.25 \mathrm{~m} 3$, pelanggan luar kota $131451.79 \mathrm{~m}^{3}$, pelanggan pelabuhan $119280.22 \mathrm{~m}^{3}$, dan pelanggan sosial $2857.92 \mathrm{~m}^{3}$.

Sedangkan untuk data konversi konsumsi ilegal ke rata-rata jumlah pemasangan baru (pelanggan baru) terhadap setiap jenis pelanggan, dapat di lihat pada tabel di bawah.

Tabel 3. Hasil Skenario Konversi Kehilangan Air Ke Jumlah Pelanggan Baru

\begin{tabular}{cc}
\hline Pelanggan & $\begin{array}{c}\text { Upaya jumlah pelanggan } \\
\text { baru }\end{array}$ \\
\hline Rumah Tangga & 266255 \\
\hline Industri & 9830 \\
\hline Instansi Pemerintah & 14841 \\
\hline Pelanggan Niaga & 135022 \\
\hline Luar Kota & 701 \\
\hline Pelabuhan & 773 \\
\hline Sosial & 32280 \\
\hline
\end{tabular}

\section{KESIMPULAN}

Berdasarkan analisa dan pemodelan yang telah di lakukan terhadap tingkat kehilangan air PDAM Surabaya, terdapat dua hal yang menyebabkan kehilangan air (water losses) yaitu kehilangan air akibat konsumsi ilegal(pelanggan tak bermeteran) dan kehilangan air karena kebocoran pipa pelanggan. Dengan pemodelan dan simulasi menggunakan sistem dinamik. Di peroleh kebijakan yang dapat di ambil oleh PDAM Surabaya untuk menekan angka kehilangan air yaitu dengan skenario do nothing, di prediksi rata-rata rasio kehilangan air hingga tahun 2035 adalah sebesar 68,6\%. Dari skenario pergantian pipa, di peroleh hasil peningkatan pendapatan sebesar 5 milyar untuk setiap pergantian 1\% pipa yang rusak(dengan batas maksimal pergantian adalah $5 \%$ pertahun), dengan peningkatan rasio pemenuhan sebesar 3,6\%. Jadi tingkat penekanan tingkat kehilangan akan tergantung pada berapa persen pipa yang dapat di perbaiki oleh PDAM setiap tahunnya. Skenario terakhir(konversi kehilangan ke pelanggan baru) menghasilkan rata-rata pelanggan Rumah tangga sebesar 266.255 pelanggan baru atau industri sebesar 9.830 pelanggan baru atau instansi pemerintah14.841 pelanggan baru atau pelanggan niaga135.022 pelanggan baru atau luar kota 701 pelanggan baru atau pelabuhan 773 pelanggan baru atau sosial 32.280 pelanggan baru. Untuk menyempurnakan penelitian ini, maka dapat di sarankan langkah penelitian selanjutnya adalah memproyeksikan rasio kebutuhan pelanggan PDAM, mengingat hingga tahun 2015, baru 50,3\% kebutuhan yang dapat terpenuhi, dan itu angka tersebut di perkirakan terus menurun.

\section{DAFTAR PUSTAKA}

[1] Andani, I. G. (2012). Peningkatan Penyediaan Air Bersih Perpipaan Kota Bandung Dengan Pendekatan Pemodelan Dinamika Sistem. Jurnal Perencanaan Wilayah dan Kota A SAPPK Vol. 1 No. 1 , 69-78.

[2] PDAM. (2013, 10). Konsumsi Air Terus Naik. Retrieved 2015, from pdam-sby.go.id: www.pdam-sby.go.id

[3] Putra, E. P. (2014). PDAM Sebut Warga Surabaya Boros Air. Republika.co.id

[4] Kementrian-PU. (2007). Penyelenggaraan Pengembangan Sistem Penyediaan Air. Kementrian Pekerjaan Umum.

[5] Soerianegara. (1977). Pengelolaan Sumber Daya Alam Bagian I. Bogor: IPB.

[6] Ryu, J. (2011). Application Of System Dynamics To Sustainable Water Resources Management In The Eastern Snake Plain Aquiver. 2nd Annual Pasific Northwest Climate Science Conference. Seattle: University Of Washington.

[7] BLH. (2012). Profil Keanekaragaman Hayati Kota Surabaya. Surabaya: lh.surabaya.go.id. 
[8] Setiawan, Iksan. (2003). Study Pemenuhan Kebutuhan Air Bersih PDAM Kota Surabaya Tahun Proyeksi (2015), Neutron, 3, 47-64.

[9] Amalia Intan Sari, B. D. (2013). Perencanaan Peningkatan Sistem Distribusi Air Minum Sumber Mata Air Umbulan di Wilayah Pelayanan Offtake Waru Kabupaten Sidoarjo . Jurnal Teknik POMITS , D10-D13.

[10] Hidayat, Tofik. (2011). Pemodelan Dinamik Analisis Investasi Untuk Meminimalisasi Tingkat Kehilangan Air (Studi Kasus Di PDAM Kota Tegal), Prosiding Seminar Nasional Sains dan Teknologi, 2, C.82-C.87.

[11] Djamal, dkk. (2009). Penurunan Kehilangan Air: Pengalaman Jakarta Setelah Kerjasama Pemerintah -Swasta1998-2008. Jakarta: Badan Regulator PAM.

[12] Richardson, G. P. (2013). System Dynamics. (S. I. Gass, \& M. C. Fu, Eds.) Encyclopedia of Operations Research and Management Science, 1519-1522.

[13] Sterman, J. D. (2000). Business Dynamics: Systems Thinking and Modeling for a Complex World. New York: Jeffrey J. Shelstad.

[14] Barlas, Y. (1996). Formal aspects of model validity and validation in system dynamics. System Dynamics Review , 12, 183-210. 
- Halaman ini sengaja dikosongkan 